\title{
Effect of Storage Time on the Quality of Smoked Hetroclarias
}

\author{
A. A. Ayeloja ${ }^{1, *}$, W. A. Jimoh ${ }^{1}$, T. O. Uthman², M. O. Shittu ${ }^{3}$ \\ تأثير وقت التخزين على جودة Hetroclarias المدخن \\ ايلوها و جيمو و عثمان و شيتو \\ АвSTRACT. In this study, the effect of storage time on the quality of smoked heteroclarias was studied. Samples (108) of \\ heteroclarias (average weight $210 \pm 15 \mathrm{~g}$ ) were used. Proximate, mineral composition ( $\mathrm{Ca}, \mathrm{Na}$, Fe and $\mathrm{Mg}$ ), biochemical, \\ amino acid and sensory characteristics were evaluated. Data obtained was subjected to Analysis of Variance (ANOVA), \\ while the sensory data was subjected to nonparametric test (i.e. Kruskal Wallis test). Smoked heteroclarias was good \\ nutritional quality in terms of compositions, such as protein, fat, carbohydrate, mineral and amino acids; however, \\ these compositions were decreased with the increase of storage at ambient temperature. Glutamic acid was the most \\ predominant amino acid and the highest non-essential amino acid (NEAA), while lysine was the most predominant \\ essential amino acid (EAA). There was higher concentration of non-essential amino acids than essential amino acids, \\ and EAA/NEAA ratio $(0.86-0.93)$ indicated that the fish was excellent in terms of protein quality. Predicted protein \\ efficiency ratio (PPER) ranged between 3.44-3.61 and its biological value ranged between 79.84-75.04. Chemical score \\ and TEAA (Total Essential Amino Acid) decreased with the increase of storage time and its texture reduced signifi- \\ cantly $\left(x^{2}=12.207, p \leq 0.01\right)$ with the increased storage period. Smoked heteroclarias could be recommended for the \\ consumption owing to its retained nutritional quality.
}

KEYWORDS: Storage time; quality; smoked; heteroclarias.

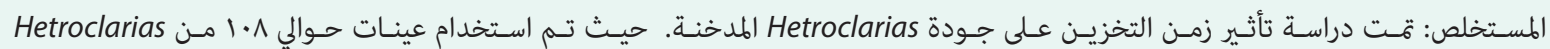

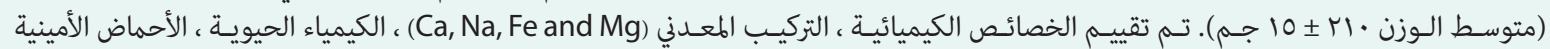

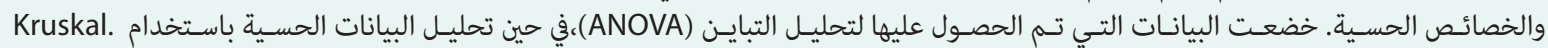
Hetroclarias كاند Wallis test

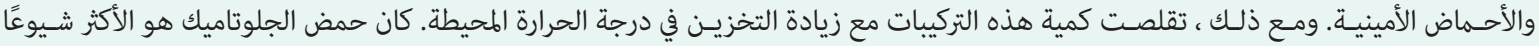

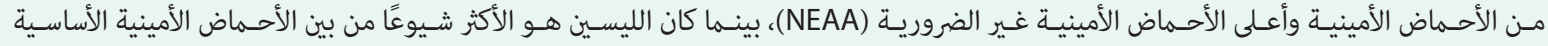

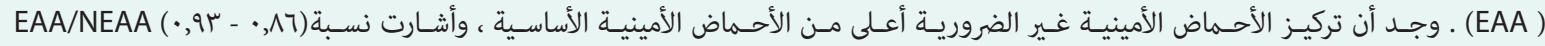

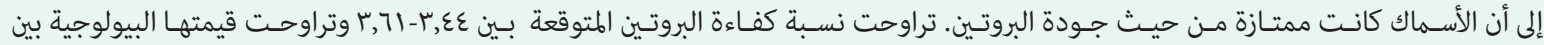

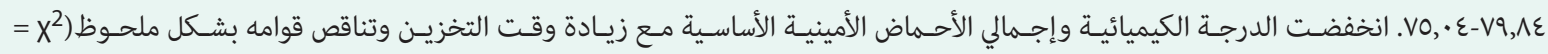

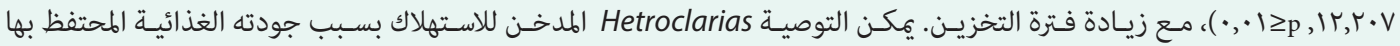

\section{Introduction}

$\mathrm{F}$ ish is one of the important source of protein, and it has high commercial and medicinal values due to the presence of essential amino acids, other nitrogenous compounds, water, lipids, carbohydrates, minerals and vitamins (Marwa, 2015; Ayeloja et al., 2011a). Zulema (2014) recommended the consumption of fish as it prevents cardiovascular and other diseases. Ravichandran et al. (2011) also reported that fish is a good source of antimicrobial peptides, which defend the body against dreadful human pathogens. Fish also contributes to income, employment generation and foreign exchange earning of many countries (Zulema, 2014). Fish contains

A. A. Ayeloja ${ }^{1,}{ }^{*}$ ayeloja2@gmail.com, ${ }^{1}$ Department of Aquaculture and Fisheries, University of Ilorin, PMB 1515 Ilorin, Kwara State, Nigeria. ${ }^{2}$ Bilogical Science Department, Tai Solarin University of Education, ljagun Ogun State, Nigeria. ${ }^{3}$ Department of Fisheries Technology, Federal College of Animal Health and Production Technology Moor Plantation, Ibadan, Nigeria.
Hetroclarias ، الكلمات المفتاحية : وقت التخزين ، الجودة ، المدخن all the essential amino acids, hence it is called "complete protein"; thereby making its consumption a necessity (Pawar and Sonawane, 2013). Heliene (2016) also stated that fish have high levels of polyunsaturated fatty acids that are important for the promotion and maintenance of health as well as minerals, such as calcium, phosphorus, sodium, potassium and magnesium. However, fish is highly perishable and considerable losses in quality could occur before consumption if not properly handled, processed and stored. Therefore, it is a concern for the fisheries industry all over the world (Huss et al., 2004). Fresh fish deteriorates very quickly after harvesting due to the actions of enzymes and bacteria (Akande, 1996). Fish quality is a complex concept involving a number of factors (Jinadasa, 2014).

To reduce fish spoilage, various preservation and processing methods are employed including freezing, chemical preservation, salting, smoking and frying (Ayeloja et al., 2018). However, smoking is one of the 
most popular method of fish processing in developing countries like Nigeria (Ayeloja, 2019). Smoking provides good taste and aroma to fish and it extends fish shelf life. This is due to the effects of dehydration, antimicrobial and antioxidant activities of several components from smoke, such as formaldehyde, carboxylic acids and phenols (Serkan et al., 2010). However, there is limited information on the effect of storage time on the quality of smoked heteroclarias, which is one of the most cultured fish species. Heteroclarias is more cultured due to its superior growth, improved survival and general hardiness than culturing the pure breed of either Clarias gariepinus or Heterobranchus bidorsalis (Obe, 2014). Owodehinde et al. (2018) reported that heterobranchus is a hybrid product of $\mathrm{H}$. bidorsalis $(\hat{\mathrm{J}}) \times \mathrm{C}$. gariepinus () which are fresh water fish. Heteroclarais is produced from the two species due to their uniqueness and prominence among commercial fish farmers in Africa and these fishes are tasty, hardy and tolerant to poor quality of growing water (Ekelemu, 2010). However, consumers rarely have information about the nutritional quality of smoked heteroclarias and its quality changes during storage, thus the need for this study. This study aimed to determine the nutritional quality of smoked heteroclarias as well as to examine the effect of ambient storage on its proximate, mineral, biochemical, amino acid and sensory qualities.

\section{Materials and Methods}

\section{Sample Collection}

Total 108 samples of heteroclarias (average weight 210 $+15 \mathrm{~g}$ ) were collected at a commercial fish farm within Ilorin metropolies, Kwara state, North-Central Nigeria. These were taken to laboratory; and were gutted, washed and smoked similar to the modified method of Ayeloja et al. (2015) (Figure 1). The smoking was performed using NIOMR (Nigeria Institute of Oceanography and Marine Research) smoking kiln, which was manually powered using charcoal as fuel. The smoked fish was stored at ambient temperature $\left(27 \pm 3^{\circ} \mathrm{C}\right)$ and samples were collected at every fortnight (i.e., 0, 14, 28, 42 and 56 days) for proximate, mineral, biochemical; and samples for organoleptic assessment and amino acid analysis were collected at day 0, 28 and 56, respectively.

\section{Composition Analysis}

Proximate compositions of fish were determined by conventional method (AOAC, 2000). Petri dish was cleaned and weighed. Then $1.0 \mathrm{~g}$ of each of the grounded fish samples was measured in each petridish and then weighed. They were each transferred into the oven at $105^{\circ} \mathrm{C}$ for 3 hours. After the first 3 hours, the petridish was removed from the oven, allowed to cool and weighed. The petridish was returned into the oven and was brought out after an hour and weighed again; this process was repeated until a constant weight was achieved and moisture content was determined.

The crude protein was determined using Kjeldahl method. The fish sample (either smoked or frozen) was ground into a fine or smooth texture. A known weight $(5.0 \mathrm{~g})$ of the fish sample is then weighed into a long necked Kjedahl flask along with $5 \mathrm{~g}$ of copper sulphate anhydrous and $5 \mathrm{~g}$ of sodium sulphate anhydrous. Then, $25 \mathrm{ml}$ of concentrated sulphuric acid $\left(\mathrm{H}_{2} \mathrm{SO}_{4}\right)$ was added. The flask was gently placed and the content was heated, the heating continued until a clear solution was obtained. The digestion was performed between 3 to 5 hours. The clear hot solution obtained was allowed to cool and solution was filtered using filter paper. Then, $5 \mathrm{ml}$ of the filtered digested sample was poured into the protein determination equipment and $10 \mathrm{ml}$ of $40 \%$ $\mathrm{NaOH}$ was added followed by a distillation process. The steam being passed in the reactor condenses and drops into a conical flask containing boric acid $(5 \mathrm{ml})$ until the mixture changes color. After changing color, $50 \mathrm{ml}$ of the liquid was collected and titrated with $0.01 \mathrm{M}$ of $\mathrm{HCl}$ until the color (green) changed to deep blue.

For the estimation of fat content, the dried samples left after moisture determination were finely ground and the fat was extracted for 4 hours with a non-polar solvent (i.e. ethyl ether) using soxhlet extraction method. After extraction, the solvent was evaporated and the extracted fat was weighed. Ash was determined by burning the dried sample in a furnace at $550^{\circ} \mathrm{C}$ for $4 \mathrm{~h}$. The difference in weights before and after burning gave the total ash content. The total carbohydrate content was determined by subtracting the sum of the percentage moisture, ash, crude lipid, and crude protein from $100 \%$.

\section{Mineral Composition and other Biochemical} Test

Crucible was cleaned, weighed and then $5.0 \mathrm{~g}$ of ground fish sample was measured into each crucible. This was transferred into the oven at $60^{\circ} \mathrm{C}$ for 45 minutes to 1 hour. After oven drying, the sample was weighed into a conical flask and was digested using nitric acid and hydrochloric acid. After digestion, the concentration of the minerals was determined using Pinnacle 900T Atomic Absorption Spectrophotometer (AAS). The Total Volatile Base Nitrogen (TVBN), trimethyl amine (TMA), $\mathrm{pH}$, peroxide value (PV) and free fatty acid (FFA) were determined following the method of Pearson (1982).

\section{Amino Acid Analysis}

The preparation of the fish samples was adapted from the procedure described by Benitez (1989). The fish samples were dried to a constant weight, defatted, and hydrolyzed (Bligh and Dyer, 1959). These were evaporated in a rotary evaporator and loaded into the Applied Biosystems PTH Amino Acid Analyzer Model 120A. 


\section{Hydrolysis}

A known weight $(2.0 \mathrm{~g})$ of the defatted sample was weighed into a glass ampoule and $7 \mathrm{ml}$ of $6 \mathrm{~N} \mathrm{HCl}$ was added. In order to avoid possible oxidation of some amino acids during hydrolysis such as methionine and cystine, nitrogen was passed into the ampoule to expel oxygen. The glass ampoule was then sealed with Bunsen burner flame and placed in an oven preset at $105 \pm 5^{\circ} \mathrm{C}$ for 22 hours. The ampoule was allowed to cool before broken open at the tip and the content was filtered to remove the humins. The filtrate was then evaporated to dryness at $40^{\circ} \mathrm{C}$ under vacuum by a rotary evaporator. The residue was dissolved with $5 \mathrm{ml}$ to acetate buffer $(\mathrm{pH} 2.0)$ and stored in plastic specimen bottles, which were kept in a freezer. It is noteworthy that hydrolysis procedure was unable to determine tryptophan since it is chemically decomposed by $6 \mathrm{~N} \mathrm{HCl}$ during acid hydrolysis.

\section{Tryptophan}

To identify tryptophan, a separate sample of the defatted sample was hydrolysed using antioxidants such as dodecanethiol to replace $6 \mathrm{~N}$ hydrochloric acid $(\mathrm{HCl})$, thereby preserving tryptophan. The tryptophan in the known sample was hydrolyzed with 4.2 M Sodium hydroxide (Maria et al., 2004). The known sample was dried to constant weight, defatted and hydrolyzed; and defatted sample $(2.0 \mathrm{~g})$ was weighed into glass ampoule. It is recommended that alkaline hydrolysis produced higher tryptophan recovery than acid hydrolysis. Sodium hydroxide was used instead of barium hydroxide to avoid problems of precipitation and adsorption of tryptophan (Maria et al., 2004). Nitrogen was passed into the ampoule to expel oxygen and it was then sealed with Bunsen burner flame. The sealed ample was placed in an oven preset at $105 \pm 5^{\circ} \mathrm{C}$ for 4 hours. The ampoule was allowed to cool and the content was filtered to remove the humins. The filtrate was then neutralized to $\mathrm{pH} 7.0$ and evaporated to dryness at $40^{\circ} \mathrm{C}$ using a rotary evaporator under vacuum. The residue was dissolved in $5 \mathrm{ml}$ of borate buffer ( $\mathrm{pH}$ 9.0) and stored in plastic specimen bottles, which were kept in a freezer.

\section{Loading of Hydrolysate into a PTH analyser}

Sixty microliter of the hydrolysate was loaded in the analyzer. This was dispensed into the cartridge of the analyzer. The analyzer is designed to separate and analyze free acidic, neutral and basic amino acids. The period of the analysis lasted for 45 minutes. To calculate amino acid values, an integrator attached to analyzer calculated the peak area proportional to the concentration of each of the amino acid. The net height of each peak produced by the chart recorder of TSM (each representing an amino acid) was measured. The half-height of the peak on the chart was found and the width of the peak on the half-height was accurately measured and record- ed. Approximate area of each peak was then obtained by multiplying the height with the width at half-height. The norleucine equivalent (NE) for each amino acid in the standard mixture was calculated using the formula:

$$
\text { Norleucine }(\mathrm{NE})=\frac{\text { Area of norleucine peak }}{\text { Area of each amino acid }}
$$

where, NE is an internal standard. A constant $\mathrm{S}$ was calculated in $\mathrm{g} / 100 \mathrm{~g}$ protein using the following formula:

$$
\mathrm{S}_{\text {std }}=\mathrm{NE}_{\text {std }} \times \text { Mol. Weight } \times \mu \mathrm{MAA}_{\text {std }}
$$

Finally, the amount of each amino acid present in the sample was calculated in $\mathrm{g} / 100 \mathrm{~g}$ protein using the formula:

Concentration $\left(\frac{\mathrm{g}}{100 \mathrm{~g}}\right.$ protein $)=\mathrm{NW} \times \mathrm{W} @ \mathrm{NH} / 2 \times \mathrm{Sstd} \times \mathrm{C}$

$C=$ Dilution $\times \frac{16}{\text { Sample }} w t(g) \times N \% \times 10$.Vol Loaded $\div N H \times W($ nleu $)(4)$

where NH is net height, W is width @ half height, nleu $=$ Norleucine. The period of analysis lasted for 45 minutes. To determine nitrogen in the separated sample for analyzing tryptophan, a $200 \mathrm{mg}$ ground sample was weighed, wrapped in whatman filter paper (No. 1) and the procedure for nitrogen determination for amino acids as described was repeated. Percentage nitrogen was calculated.

\section{Predicted Protein Efficiency Ratio (PPER)}

The predicted protein efficiency ratio (PPER) was estimated by using the equation given by Alsmeyer et al. (1974):

PPER $=-0.468+0.454($ Leu $)-0.105($ Tyr $)$.

\section{Amino Acid Score (AAS)}

The essential amino acid score was calculated based on the whole hen's egg amino acid profiles (Paul and Southgate, 1976)

Amino acid score $=\frac{\text { Amount of amino acid per test protein }(\mathrm{g} / 100 \mathrm{~g})}{\text { Amount of amino acid per protein in reference }(\mathrm{g} / 100 \mathrm{~g})}$

\section{Essential Amino Acid Index (EAAI)}

The essential amino acid index (EAAI) was calculated using the ratio of test protein to the reference protein for each ten essential amino acids (Oser, 1959) as:

EAAI $=\sqrt[n]{\frac{\text { lysine } P}{\text { Lysine } S} \times \frac{\text { tryptophan } P}{\text { tryptophan } S} \times \ldots \times \frac{\text { threonine } P}{\text { threonine } S}}$

where, $\mathrm{P}$ is test protein, and $\mathrm{S}$ is standard whole egg protein. 


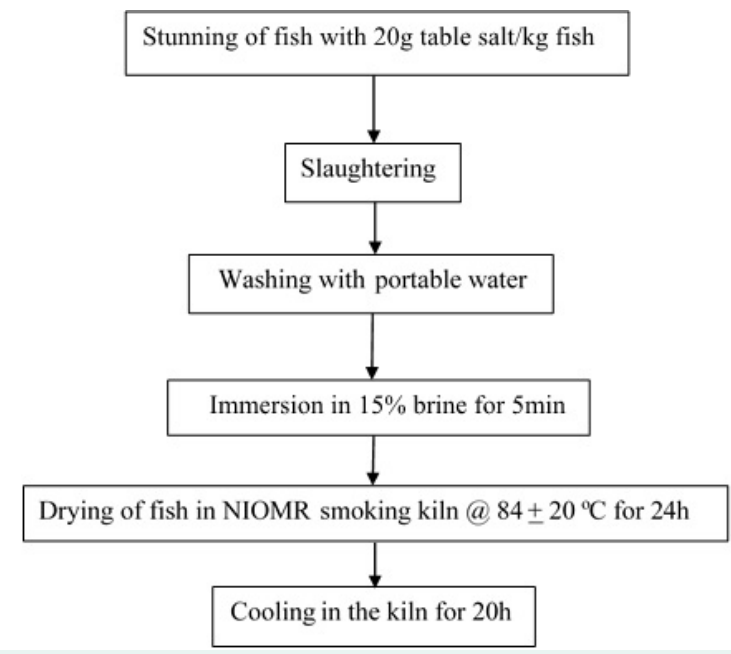

Figure 1. Flow chart for the production of smoked catfish heteroclarias

\section{Biological Value (BV)}

The Biological Value (BV) was calculated by the method of Oser (1959): $\quad$ BV= 1.09 (EAAI) - 11.73

\section{Organoleptic Assessment}

The various smoked fish species were subjected to consumer preference evaluation using based on 5-point hedonic scale modified from Tobor (1994) and Eyo (2001). Odor, flavor and texture were the sensory attributes examined, the following grades were allotted depending on their qualities: $8 \leq 10=$ Excellent, $6 \leq 8=$ Very good, $4 \leq 6=$ good, $2 \leq 4=$ bad and $\leq 2=$ worst. Thirty semi-trained panelists from Department of Aquaculture and Fisheries, Faculty of Agriculture University of Ilorin Kwara State, Nigeria were used for the assessment.

\section{Statistical Analysis}

SPSS 16.0 version was used for the statistical analysis. Data collected on descriptive organoleptic assessment using hedonic scale were subjected to nonparametric test (Kruskal Wallis test). While other data were subjected to Analysis of variance (ANOVA) using F-test to determine the significant difference between the treatments. Means of the significantly different treatments were separated using Duncan multiple range test at 95\% confidence value. Samples for laboratory analysis were replicated thrice to aid statistical analysis.

\section{Results}

The result for the proximate composition of smoked Heteroclarias is presented on Table 1 . The result indicates that the moisture content of smoked Heteroclarias ranged from $26.44 \pm 0.01$ to $27.37 \mathrm{~g} / 100 \mathrm{~g}$ sample \pm 0.06 within a storage time of 56 days. The highest moisture content $(27.37 \mathrm{~g} / 100 \mathrm{~g}$ sample \pm 0.06$)$ was recorded on the $56^{\text {th }}$ day of storage, while the lowest moisture content $26.44 \mathrm{~g} / 100 \mathrm{~g}$ sample \pm 0.01 was recorded on day 0 ; which was immediately after smoking. The moisture content of the fish increased significantly $(p \leq 0.05)$ with the increased storage time through the period of the storage ( 56 days). The percentage crude protein content of the fish ranged from $45.37 \mathrm{~g} / 100 \mathrm{~g}$ sample \pm 0.15 to $48.96 \mathrm{~g} / 100 \mathrm{~g}$ sample \pm 0.03 within a storage time of 56 days. There was no significant difference $(p>0.05)$ in the crude protein content for the first 14 days of storage but later significantly increased $(p \leq 0.05)$ from day 28 until storage period. The highest crude protein value of 48.96 $\mathrm{g} / 100 \mathrm{~g}$ sample \pm 0.03 was recorded on the day 0 before fish was stored at ambient, while the lowest value of $45.37 \mathrm{~g} / 100 \mathrm{~g}$ sample \pm 0.15 was recorded on the $56^{\text {th }}$ day of storage.

The crude lipid content of the fish ranged between $18.73 \pm 0.12$ to $20.42 \mathrm{~g} / 100 \mathrm{~g}$ sample \pm 0.02 within a storage period of 56 days. The highest crude lipid content $(20.42 \mathrm{~g} / 100 \mathrm{~g}$ sample \pm 0.02$)$ was recorded at day 0 , which was the lowest crude lipid content $(18.73 \mathrm{~g} / 100$ $g$ sample \pm 0.12 ) was recorded on the $56^{\text {th }}$ day of storage. The lipid content of the fish decreased significantly $(p \leq 0.05)$ with the increased storage time through the storage period (56 days). The ash content of the fish differed significantly $(p \leq 0.05)$ during the first 14 days of storage. However, there was no significant difference ( $p>0.05$ ) in the ash content of the fish from day 28 until the remaining period of storage. The percentage carbohydrate content of smoked Heteroclarias ranged between $2.02 \pm 0.01$ to $6.38 \mathrm{~g} / 100 \mathrm{~g}$ sample \pm 0.27 during the storage period of 56 days. No significant difference ( $p>0.05$ ) was observed for the first 2 weeks of storage but later significantly differed ( $\mathrm{p} \leq 0.05)$ from 28 days un-

Table 1. Proximate composition ( $\mathrm{g} / 100 \mathrm{~g}$ sample) of smoked Heteroclarias with increased storage time

\begin{tabular}{|c|c|c|c|c|c|}
\hline & Day 0 & Day 14 & Day 28 & Day 42 & Day 56 \\
\hline Moisture & $26.44 \pm 0.01^{a}$ & $26.78 \pm 0.02^{b}$ & $26.91 \pm 0.08^{C}$ & $27.17 \pm 0.05^{d}$ & $27.37 \pm 0.06^{\mathrm{e}}$ \\
\hline Crude protein & $48.96 \pm 0.03^{d}$ & $48.96 \pm 0.02^{d}$ & $46.86 \pm 0.08^{c}$ & $45.91 \pm 0.08^{b}$ & $45.37 \pm 0.15^{\mathrm{a}}$ \\
\hline Crude lipid & $20.42 \pm 0.02^{d}$ & $20.02 \pm 0.01^{c}$ & $19.00 \pm 0.20^{b}$ & $18.94 \pm 0.12^{\mathrm{ab}}$ & $18.73 \pm 0.12^{\mathrm{a}}$ \\
\hline Ash & $2.16 \pm 0.02^{\mathrm{a}}$ & $2.24 \pm 0.01^{b}$ & $2.16 \pm 0.03^{\mathrm{a}}$ & $2.16 \pm 0.03^{a}$ & $2.15 \pm 0.02^{\mathrm{a}}$ \\
\hline $\mathrm{CHO}$ (Carbohydrate) & $2.02 \pm 0.01^{\mathrm{a}}$ & $2.01 \pm 0.01^{\mathrm{a}}$ & $5.07 \pm 0.16^{b}$ & $5.82 \pm 0.21^{c}$ & $6.38 \pm 0.27^{d}$ \\
\hline
\end{tabular}


Table 2. Mineral composition of smoked Heteroclarias (mg/100 $\mathrm{g}$ ash) with increased storage time

\begin{tabular}{|lrrrrr}
\hline Mineral & Day 0 & Day 14 & Day 28 & Day 42 & Day 56 \\
& & & & & \\
\hline Calcium (Ca) & $6.15 \pm 0.07^{\mathrm{d}}$ & $5.85 \pm 0.07^{\mathrm{c}}$ & $5.60 \pm 0.00^{\mathrm{b}}$ & $5.44 \pm 0.06^{\mathrm{a}}$ & $5.33 \pm 0.04^{\mathrm{a}}$ \\
Sodium (Na) & $1.05 \pm 0.07^{\mathrm{b}}$ & $0.95 \pm 0.07^{\mathrm{b}}$ & $0.81 \pm 0.01^{\mathrm{a}}$ & $0.77 \pm 0.02^{\mathrm{a}}$ & $0.70 \pm 0.01^{\mathrm{a}}$ \\
Iron (Fe) & $0.41 \pm 0.01^{\mathrm{d}}$ & $0.39 \pm 0.01^{\mathrm{d}}$ & $0.34 \pm 0.02^{\mathrm{c}}$ & $0.28 \pm 0.03^{\mathrm{b}}$ & $0.21 \pm 0.01^{\mathrm{a}}$ \\
Magnesium (Mg) & $4.35 \pm 0.21^{\mathrm{d}}$ & $3.95 \pm 0.07^{\mathrm{c}}$ & $3.45 \pm 0.07^{\mathrm{b}}$ & $3.25 \pm 0.07^{\mathrm{ab}}$ & $3.00 \pm 0.00^{\mathrm{a}}$
\end{tabular}

*Mean with different superscript in the row indicates significant difference at $p<0.05$

Table 3. Effect of storage time on biochemical quality of smoked Heteroclarias.

\begin{tabular}{|cccccc}
\hline & TMA $(\mathrm{mgN} / 100 \mathrm{~g})$ & TVBN $(\mathrm{mgN} / 100 \mathrm{~g})$ & $\mathrm{pH}$ & PV (mEq. Peroxide/kg) & FFA (g/100 g fat) \\
\hline Day 0 & $21.02+0.01^{\mathrm{a}}$ & $30.37+0.01^{\mathrm{a}}$ & $7.43+0.06^{\mathrm{a}}$ & $8.47+0.01^{\mathrm{b}}$ & $7.83+0.02^{\mathrm{c}}$ \\
Day 14 & $22.50+0.02^{\mathrm{b}}$ & $31.50+0.01^{\mathrm{c}}$ & $7.57+0.06^{\mathrm{c}}$ & $8.70+0.01^{\mathrm{e}}$ & $7.41+0.01^{\mathrm{b}}$ \\
Day 28 & $24.09+0.11^{\mathrm{c}}$ & $32.86+0.02^{\mathrm{d}}$ & $7.43+0.06^{\mathrm{d}}$ & $8.65+0.01^{\mathrm{d}}$ & $7.38+0.03^{\mathrm{b}}$ \\
Day 42 & $24.16+0.02^{\mathrm{c}}$ & $32.73+0.56^{\mathrm{d}}$ & $7.63+0.06^{\mathrm{d}}$ & $8.61+0.01^{\mathrm{c}}$ & $7.40+0.00^{\mathrm{b}}$ \\
Day 56 & $21.08+1.14^{\mathrm{a}}$ & $30.95+0.07^{\mathrm{b}}$ & $7.63+0.06^{\mathrm{b}}$ & $8.22+0.01^{\mathrm{a}}$ & $6.92+0.00^{\mathrm{a}}$
\end{tabular}

Means $\pm S D$ with different superscript in the same column indicating significant differences at $P \leq 0.05$.

Note: TMA = Trimethylamine, TVBN= Total Volatile Base Nitrogen, PV= Peroxide Value, FFA= Free Fatty Acid.

til the remaining 56 days of storage.

Table 3 presents the effect of storage time on biochemical quality of smoked Heteroclarias. The highest TMA value $(24.16 \pm 0.02 \mathrm{mgN} / 100 \mathrm{~g})$ and the lowest value $(21.02 \pm 0.01 \mathrm{mgN} / 100 \mathrm{~g})$ was recorded with values increasing significantly $(P \leq 0.05)$ from day 0 to day 42 of storage time and decreased significantly $(P>0.05)$ from day 42 to day 56 of storage time. The highest TVBN value $(32.86 \pm 0.02 \mathrm{mgN} / 100 \mathrm{~g})$ and the lowest $(30.37 \pm$ $0.01 \mathrm{mgN} / 100 \mathrm{~g}$ ) was recorded. It was observed that the TVBN increased significantly $(P \leq 0.05)$ from day 0 to day 28 of storage time and decreased significantly ( $P>0.05)$ from day 28 to day 56 . The $\mathrm{pH}$ had no significant differences $(P>0.05)$ with increased in storage time. The PV had no significant differences $(P>0.05)$ with the increase in storage time. The highest FFA $(7.83 \mathrm{~g} / 100 \mathrm{~g}$ fat \pm 0.02$)$ and the lowest value $(6.92 \mathrm{~g} / 100 \mathrm{~g}$ fat \pm 0.00$)$ was observed. However, FFA decreased significantly $(P>0.05)$ from day 0 to day 28 and slightly increased significantly at day 42 but decreased significantly from day 42 to day 56 of storage time.

\section{Amino Acid Profile}

The amino acid profile of Heteroclarias spp. muscles at different storage time (day 0 , day 28 and day 56) are presented in Table 4. Eighteen amino acids (10 essential, 8 non-essential) were observed in the fish with their mean values as shown in the Table 4. The highest and lowest mean value at day 0 was observed in glutamic acid (14.38 $\mathrm{g} / 100 \mathrm{~g}$ crude protein, $\mathrm{cp})$ and tryptophan $(0.84 \mathrm{~g} / 100$ $\mathrm{g} \mathrm{cp}$ ) respectively. The highest and lowest mean value at day 28 was observed in glutamic acid $(13.36 \mathrm{~g} / 100 \mathrm{~g}$ $\mathrm{cp})$ and tryptophan $(0.87 \mathrm{~g} / 100 \mathrm{~g} \mathrm{cp})$, respectively. The highest and lowest mean value at day 56 was observed in glutamic acid (14.91 g/100 g cp) and cystine (0.61 g/100 $\mathrm{g}(\mathrm{cp})$, respectively. An increase in amino acid content was observed across storage time (i.e. as storage time increases) in leucine (from $7.28 \pm 0.10$ to $7.36 \pm 0.08$ to 7.59 $\pm 0.29 \mathrm{~g} / 100 \mathrm{~g} \mathrm{cp}$ ) and aspartic acid (from $9.91 \pm 0.02$ to $10.00 \pm 0.03$ to $9.97 \pm 0.11 \mathrm{~g} / 100 \mathrm{~g} \mathrm{cp}$ ), which increased at day 28 but decreased slightly at day 56 . Decrease content was observed across storage time in valine (from $5.00 \pm$ 0.04 to $4.65 \pm 0.08$ to $3.74 \pm 0.08 \mathrm{~g} / 100 \mathrm{~g} \mathrm{cp}$ ), methionine (from $2.94 \pm 0.08$ to $2.33 \pm 0.10$ to $1.74 \pm 0.04 \mathrm{~g} / 100 \mathrm{~g}$ $\mathrm{cp}$ ), glycine (from $8.18 \pm 0.18$ to $8.15 \pm 0.17$ to $5.25 \pm$ $0.10 \mathrm{~g} / 100 \mathrm{~g} \mathrm{cp}$ ), tyrosine (from $3.19 \pm 0.12$ to $2.93 \pm 0.25$ to $2.92 \pm 0.11 \mathrm{~g} / 100 \mathrm{~g} \mathrm{cp}$ ) and serine (from $4.81 \pm 0.08$ to $4.62 \pm 0.11$ to $3.77 \pm 0.10 \mathrm{~g} / 100 \mathrm{~g} \mathrm{cp}$ ). In phenylalanine (from $4.43 \pm 0.00$ to $3.72 \pm 0.00 \mathrm{~g} / 100 \mathrm{~g} \mathrm{cp}$ ), tryptophan (from $0.87 \pm 0.04$ to $1.73 \pm 0.00 \mathrm{~g} / 100 \mathrm{~g} \mathrm{cp}$ ), proline (from $6.14 \pm 0.21$ to $4.42 \pm 0.08 \mathrm{~g} / 100 \mathrm{~g} \mathrm{cp}$ ), arginine (from 6.88 \pm 0.25 to $6.20 \pm 0.1 \mathrm{~g} / 100 \mathrm{~g} \mathrm{cp}$ ), histidine (from $2.27 \pm$ 0.04 to $2.09 \pm 0.11 \mathrm{~g} / 100 \mathrm{~g} \mathrm{cp}$ ), cystine (from $0.97 \pm 0.00$ to $0.61 \pm 0.00 \mathrm{~g} / 100 \mathrm{~g} \mathrm{cp}$ ) and alanine (from $6.43 \pm 0.08$ to $5.80 \pm 0.06 \mathrm{~g} / 100 \mathrm{~g} \mathrm{cp}$ ), an increase was observed at day 28 , followed by a decreased at 56 days after smoking. Decrease was observed at day 28 with an increase at day 56 in lysine (from $8.54 \pm 0.00$ to $8.51 \pm 0.04$ to $8.91 \pm 0.49$ $\mathrm{g} / 100 \mathrm{~g} \mathrm{cp}$ ), isoleucine (from $4.23 \pm 0.05$ to $3.11 \pm 0.62$ to $4.01 \pm 0.07 \mathrm{~g} / 100 \mathrm{~g} \mathrm{cp}$ ), glutamic acid (from $14.38 \pm 0.21$ to $13.36 \pm 0.06$ to $14.91 \pm 0.11 \mathrm{~g} / 100 \mathrm{~g} \mathrm{cp}$ ) and threonine (from $4.36 \pm 0.04$ to $3.80 \pm 0.20$ to $5.00 \pm 0.01 \mathrm{~g} / 100 \mathrm{~g}$ $\mathrm{cp})$. In one-way ANOVA test of the samples, no significant difference $(p>0.05)$ was observed in leucine, lysine, 
Table 4. Changes in amino acid profile $(\mathrm{g} / 100 \mathrm{~g} \mathrm{cp})$ of hybrid catfish (Heteroclarias spp) across storage time

\begin{tabular}{|c|c|c|c|}
\hline Amino acids & Day 0 & Day 28 & Day 56 \\
\hline \multicolumn{4}{|l|}{$\begin{array}{l}\text { Essential } \\
\text { (g/100 g protein) }\end{array}$} \\
\hline Leucine & $7.28 \pm 0.10^{a}$ & $7.36 \pm 0.08^{a}$ & $7.59 \pm 0.29^{a}$ \\
\hline Lysine & $8.54 \pm 0.00^{\mathrm{a}}$ & $8.51 \pm 0.04^{a}$ & $8.91 \pm 0.49^{a}$ \\
\hline Isoleucine & $4.23 \pm 0.05^{\mathrm{a}}$ & $3.11 \pm 0.62^{\mathrm{a}}$ & $4.01 \pm 0.07^{\mathrm{a}}$ \\
\hline Phenylalanine & $4.00 \pm 0.14^{b}$ & $4.43 \pm 0.00^{\mathrm{a}}$ & $3.72 \pm 0.00^{C}$ \\
\hline Tryptophan & $0.84 \pm 0.05^{b}$ & $0.87 \pm 0.04^{b}$ & $1.73 \pm 0.00^{\mathrm{a}}$ \\
\hline Valine & $5.00 \pm 0.04^{a}$ & $4.65 \pm 0.08^{b}$ & $3.74 \pm 0.08^{C}$ \\
\hline Methionine & $2.94 \pm 0.08^{a}$ & $2.33 \pm 0.10^{b}$ & $1.74 \pm 0.04^{c}$ \\
\hline Arginine & $6.67 \pm 0.06^{\mathrm{ab}}$ & $6.88 \pm 0.25^{a}$ & $6.20 \pm 0.12^{b}$ \\
\hline Threonine & $4.36 \pm 0.04^{b}$ & $3.80 \pm 0.20^{C}$ & $5.00 \pm 0.01^{\mathrm{a}}$ \\
\hline Histidine & $2.19 \pm 0.02^{\mathrm{a}}$ & $2.27 \pm 0.04^{\mathrm{a}}$ & $2.09 \pm 0.11^{\mathrm{a}}$ \\
\hline \multicolumn{4}{|l|}{$\begin{array}{l}\text { Non Essential } \\
(\mathrm{g} / 100 \mathrm{~g})\end{array}$} \\
\hline Cystine & $0.85 \pm 0.00$ & $0.97 \pm 0.00$ & $0.61 \pm 0.00$ \\
\hline Alanine & $6.41 \pm 0.16^{a}$ & $6.43 \pm 0.08^{a}$ & $5.80 \pm 0.06^{b}$ \\
\hline Glutamic acid & $14.38 \pm 0.21^{b}$ & $13.36 \pm 0.06^{c}$ & $14.91 \pm 0.11^{a}$ \\
\hline Glycine & $8.18 \pm 0.18^{a}$ & $8.15 \pm 0.17^{a}$ & $5.25 \pm 0.10^{b}$ \\
\hline Serine & $4.81 \pm 0.08^{\mathrm{a}}$ & $4.62 \pm 0.11^{\mathrm{a}}$ & $3.77 \pm 0.10^{b}$ \\
\hline Aspartic acid & $9.91 \pm 0.02^{\mathrm{a}}$ & $10.00 \pm 0.03^{a}$ & $9.97 \pm 0.11^{\mathrm{a}}$ \\
\hline Proline & $5.69 \pm 0.44^{\mathrm{a}}$ & $6.14 \pm 0.21^{\mathrm{a}}$ & $4.42 \pm 0.08^{b}$ \\
\hline \multirow[t]{2}{*}{ Tyrosine } & $3.19 \pm 0.12^{\mathrm{a}}$ & $2.93 \pm 0.25^{\mathrm{a}}$ & $2.92 \pm 0.00^{\mathrm{a}}$ \\
\hline & $2.93 \pm 0.25^{a}$ & $2.92 \pm 0.00^{\mathrm{a}}$ & \\
\hline
\end{tabular}

Means $\pm S D$ with different superscript in the same column indicating significant differences at $\mathrm{P} \leq 0.05$.

isoleucine, cystine, tyrosine, aspartic acid and histidine content of the sample throughout the storage period. A significant difference $(p \leq 0.05)$ was noticed in phenylalanine, threonine, glutamic acid, valine and methionine content of the sample at all storage times. No significant difference was observed in arginine between the periods of $0-28$ days and $0-56$ days of storage ( $p>0.05)$, however a significant difference was noticed between 28 and 56 days of storage $(p \leq 0.05)$. Alanine, tryptophan, proline, glycine and serine showed similar trend of no significant difference ( $p>0.05)$ at day 0 and 28 days, but a statistical variation $(p \leq 0.05)$ was noted at 56 days of storage.

Table 5 shows the protein quality parameters of Heteroclarias as a function of storage time. A decrease in total amino acid was observed with the increased storage time. A higher concentration of total non-essential amino acid was recorded than total essential amino acid. The table also records the ratio of EAA to NEAA, which was 0.86 at the beginning of the storage period, decreased slightly at day 28 to 0.84 and slightly increased at
Table 5 . Changes in quality parameters of amino acid profile of Heteroclarias with increased storage time.

\begin{tabular}{|c|c|c|c|}
\hline $\begin{array}{l}\text { Protein Quality } \\
\text { Parameters }\end{array}$ & Day 0 & Day 28 & Day 56 \\
\hline TAA $(g / 100 g)$ & 99.47 & 96.81 & 92.38 \\
\hline TEAA (g/100g) & 46.05 & 44.21 & 44.33 \\
\hline TNEAA ( $\mathrm{g} / 100 \mathrm{~g})$ & 53.42 & 52.60 & 47.65 \\
\hline EAA/NEAA & 0.86 & 0.84 & 0.93 \\
\hline CS (g/100g) & 53.33 & 51.67 & 50.13 \\
\hline EAAI & 0.84 & 0.80 & 0.83 \\
\hline BV & 79.84 & 75.04 & 78.36 \\
\hline PPER $(\mathrm{g} / 100 \mathrm{~g})$ & 3.44 & 3.50 & 3.61 \\
\hline
\end{tabular}

Note: $\mathrm{TAA}=$ total amino acids; $\mathrm{TEAA}=$ total essential amino acid; $T N E A A=$ total non-essential amino acid; $E A A I=$ essential amino acid index; $\mathrm{CS}=$ chemical score; $\mathrm{BV}=$ biological value; PPER= predicted protein efficiency ratio.

day 56 to 0.93 . Tryptophan was recorded as the limiting amino acid in the sample with chemical scores of 0.47 and 0.48 at day 0 and day 28 respectively while at day 56 , valine was recorded as the limiting amino acid in the sample with chemical scores of 0.50 . The highest EAAI value of 0.84 was recorded at day 1 and decreased to 0.80 and increased slightly to 0.83 at day 28 and day 56, respectively. The predicted protein efficiency ratio (PPER) ranged between 3.44 to $3.61 \mathrm{~g} / 100 \mathrm{~g} \mathrm{cp}$. The highest and least biological values were recorded in day 0 and day 28 , respectively.

Table 6 indicates the amino acid scores of the fish in relation to the amino acid scoring pattern of whole hen's egg protein. The values were found to be favorable in fish sample at day 0 of smoking and decreased at the end of storage period. Lysine had the highest amino acid score ranging from 1.37 to $1.38 \mathrm{~g} / 100 \mathrm{~g} \mathrm{cp}$. Tryptophan and valine were observed as the limiting amino acid with values ranging between 0.47 to $0.96 \mathrm{~g} / 100 \mathrm{~g} \mathrm{cp}$ and 0.50 to $0.67 \mathrm{~g} / 100 \mathrm{~g} \mathrm{cp}$, respectively.

In Table 7, the taste panelist scores allotted for texture of smoked Heteroclarias reduced significantly $\left(x^{2}=\right.$ $12.207, \mathrm{p} \leq 0.01)$ with increased storage period, whereas no significant $\left(X^{2}=1.628,8.982, p>0.05\right)$ decrease in the physical quality of odor and flavor was observed during storage period.

\section{Discussion}

The result of the proximate composition of smoked Heteroclarias (Table 1) was similar to that reported for other smoked fresh water fishes (Ayeloja et al., 2011a; Abraha et al., 2018). The result indicated that crude protein varied within 48.96 and $45.3 \mathrm{~g} / 100 \mathrm{~g}$ sample) and it reduced with the increase of storage time. The reduction of lipid was observed, while the moisture and carbohydrate were increased with the increase of storage time. Sim- 
Table 6. Amino acid scores and Indispensable Amino acid index (IAAI) of Heteroclarias

\begin{tabular}{|c|c|c|c|c|c|}
\hline \multirow[b]{2}{*}{ Essential amino acids } & \multicolumn{3}{|c|}{ Amino acid scores $(\mathrm{g} / 100 \mathrm{~g})$} & \multirow[b]{2}{*}{$\begin{array}{l}\text { Whole egg protein } \\
\text { (g/100 g sample) }\end{array}$} & \multirow[b]{2}{*}{$\begin{array}{l}\text { FAO/WHO provisional } \\
\text { amino acid scoring pattern } \\
(\mathrm{g} / 100 \mathrm{~g})\end{array}$} \\
\hline & Day 1 & Day 28 & Day 56 & & \\
\hline Leucine & 0.88 & 0.89 & 0.91 & 8.3 & 7.0 \\
\hline Lysine & 1.38 & 1.37 & 1.37 & 6.2 & 5.5 \\
\hline Isoleucine & 0.76 & 0.56 & 0.72 & 5.6 & 4.0 \\
\hline Phenylalanine & 0.78 & 0.87 & 0.73 & 5.1 & + tyr 6.0 \\
\hline Tryptophan & 0.47 & 0.48 & 0.96 & 1.8 & 1.0 \\
\hline Valine & 0.67 & 0.62 & 0.50 & 1.5 & 5.0 \\
\hline Methionine & 0.92 & 0.73 & 0.54 & 3.2 & +cys 3.5 \\
\hline Arginine & 1.09 & 1.13 & 1.02 & 6.1 & \\
\hline Histidine & 0.83 & 0.91 & 0.95 & 2.4 & \\
\hline Threonine & 0.85 & 0.75 & 0.98 & 5.1 & 4.0 \\
\hline EAAI & 0.84 & 0.80 & 0.83 & & \\
\hline
\end{tabular}

EAAI = essential amino acid index; Whole hen's egg protein: adopted from Paul and Southgate (1976); FAO/WHO provisional amino acid scoring pattern: FAO/WHO (1973)

ilar results were reported by Ayeloja et al., 2011b and Mosarrat et al. (2016). They mentioned these changes could induce the gradual degradation of initial crude protein to more volatile products, such as total volatile bases, hydrogen sulphide and ammonia. Table 2 shows that Ca (6.15-5.33 mg/100 g ash) was the most abundant mineral in smoked heteroclaraias followed by Mg (4.35$3.00 \mathrm{mg} / 100 \mathrm{~g}$ ash). Adeyemi et al. (2013a) observed similar result in the case of Trachurus trachurus. They reported that calcium was the most abundant mineral in raw and smoked Trachurus trachurus. Table 3 shows that the TMA, TVBN, pH and PV of smoked heterobranchus increased significantly $(P>0.05)$ with increase storage time until 42days, while the FFA decreased with the increase in storage time. Khanipour and Mirzakhani (2013) reported that the $\mathrm{pH}, \mathrm{PV}$ and TVB-N values of hot smoked rainbow trout (Oncorhynchus mykiss) increased with increasing storage time. Mosarrat et al. (2016) also reported an increase of TVBN of smoked Chapila (Hamilton-Buchanan, 1822), Kaika (Hamilton-Buchanan, 1822) and Baim (Hamilton-Buchanan, 1822) when stored at ambient temperature, which was attributed to the formation of volatile amine compounds by autolytic process. Adeyemi et al. (2013b) also gave similar report that the TVBN of smoked Trachurus trachurus increased from $28.12 \pm 0.38 \mathrm{mg} \mathrm{N} / 100 \mathrm{~g}$ to $31.90 \pm 0.3 \mathrm{mgN} / 100 \mathrm{~g}$ during storage. The recommended limit of acceptability of TVBN for fish is $20-30 \mathrm{mg} \mathrm{N}$ per $100 \mathrm{~g}$ (Daramola et al., 2007), while Kirk and Sawyer suggested a value of $30-40$ $\mathrm{mg} \mathrm{N} / 100 \mathrm{~g}$ as the upper limits. The results in this study was observed within these values. The values recorded for PV in this study $(8.22-8.70)$ is lower than those reported by Adeyeye et al. (2015) for smoked fishes sold in
Lagos Nigeria (9.05 - 9.35 eroxide/kgrespectively). Eighteen amino acids (10 essentials, 8 non-essentials) were observed in heteroclarias (Table 4). Glutamic acid had the highest concentration among the amino acid and the non-essential amino acids while tryptophan was the least concentrated. While lysine was the most concentrated essential amino acid and tryptophan was the least concentrated essential amino acid in the fish. The amino acids reduced significantly $(p<0.05)$ with the increase in storage time. Shiming et al. (2013) equally observed that glutamic acid was the most predominant amino acid and the non-essential amino acid in yellowfin tuna (Thunnus Albacares) and big eye tuna (Thunnus Obesus), while the lysine was the most predominant essential amino acid. This study established that heteroclarias contained amino acid as required by human. The glycine is major component of human skin collagen, together with other amino acids such as alanine, proline, arginine, serine, isoleucine, and phenylalanine form polypeptides (Zhao et al., 2010). A decrease in protein quality parameters of Heteroclarias with the increase in storage time was observed in this study (Table 5). A higher concentration of total non-essential amino acid was recorded than total essential amino acid. EAA to NEAA ratio is an index to define the quality of the protein (EIShehawy et al., 2016). The ratio of EAA to NEAA in this study ranged between 0.86 and 0.93 which was higher than 0.71 as reported for gilt head sea bream (Sparus aurata) and 0.65 reported for sea urchin roe (Pinto, 2007). The chemical score and TEAA decreased with the increase in storage time, the EAAI ranged between 0.84 and 0.80 . The predicted protein efficiency ratio (PPER) ranged between 3.44 to $3.61 \mathrm{~g} / 100 \mathrm{~g} \mathrm{cp}$ was higher than 2.22 as recorded for $C$. 
Table 7. Effect of storage time on organoleptic quality (i.e. consumer preference) of smoked Heteroclarias

$\begin{array}{lcccccccc} & \text { Day 0 } & \text { Day } 14 & \text { Day } 28 & \text { Day } 42 & \text { Day } 56 & x^{2} & \text { P-value } \\ \text { Odor } & 8.27 & 7.80 & 8.00 & 7.73 & 8.00 & 1.63 & 0.80 \\ \text { Flavor } & 8.87 & 7.90 & 8.07 & 7.93 & 8.73 & 8.98 & 0.06 \\ \text { Texture } & 9.33 & 8.00 & 8.00 & 7.93 & 8.33 & 12.21^{*} & 0.02\end{array}$

Kruskal Wallis test $\left(x^{2}\right)$ is significant along the row $P \leq 0.05$.

anguillaris and 1.92 recorded for $O$. niloticus (Adeyeye et al. 2009). The biological value of heteroclarias ranged between 79.84 to 75.04 . Table 6 shows that the amino acid scored as compared to egg protein. The values obtained for smoked heteroclarias were found to be far lower than that of whole egg and it decreased with the increase of storage period. Lysine had the highest amino acid score ranging from 1.37 to $1.38 \mathrm{~g} / 100 \mathrm{~g} \mathrm{cp}$, while the values for tryptophan and valine were observed to be very low ranging between 0.47 to $0.96 \mathrm{~g} / 100 \mathrm{~g} \mathrm{cp}$ and 0.50 to $0.67 \mathrm{~g} / 100 \mathrm{~g} \mathrm{cp}$, respectively. The quality of the texture of smoked heteroclarias (Table 7$)$ reduced significantly ( $x^{2}$ $=12.207, \mathrm{p} \leq 0.01)$ with increased storage period. However, the taste panel observed no significant $\left(x^{2}=1.628\right.$, $8.982, p>0.05$ ) decrease in the odor and flavor of the fish during the storage period.

\section{Conclusion}

This study established that smoked heteroclarias had good nutritional quality in terms of compositions, which decreased with the increase of storage at ambient temperature. Minerals were abundant with highest $\mathrm{Ca}$ followed by Mg. Glutamic acid was the most predominant amino acid and the non-essential amino acids and tryptophan was the least concentrated; while lysine was the most predominant essential amino acid and tryptophan was the least concentrated essential amino acid in the fish. This study established that heteroclarias could provide good concentration of amino acid as require for human. The ratio of EAA to NEAA ranged between 0.86 and 0.93 and the predicted protein efficiency ratio (PPER) obtained in this study was higher than many other fish species. The biological value of heteroclarias ranged between 79.84 and 75.04 . Its chemical score and TEAA decreased with increase in storage time. However, its texture quality reduced significantly $\left(X^{2}=12.207\right.$, $\mathrm{p} \leq 0.01$ ) with increased storage period.

\section{References}

Abraha B, Admassu H, Mahmud A, Tsighe N, Shui XW, Fang Y. (2018). Effect of processing methods on nutritional and physico-chemical composition of fish: a review. MOJ Food Process Technology 6(4): 376『382.

Adeyeye SAO, Oyewole OB, Obadina AO, Omemu AM, Adeniran OE, Oyedele HA, Abayomi SO. (2015). Quality and Safety Assessment of Traditional Smoked fish from Lagos State, Nigeria. International Journal of Aquaculture 5(15): 1-9.

Adeyeye El. (2009). Amino acid composition of three species of Nigerian fish: Clarias anguillaris, Oreochromis niloticus and Cynoglossus senegalensis. Journal of Food Chemistry 113:43-46.

Adeyemi OT, Osilesi OO, Onajobi F, Adebawo O, Oyedemi SO, Afolayan AJ. (2013a). Effect of Processing on the Proximate and Mineral Compositions of Trachurus Trachurus: A Fish Commonly Consumed in Nigeria. Journal of Emerging Trends in Engineering and Applied Sciences 4(3):378-385

Adeyemi OT, Osilesi OO, Onajobi F, Adebawo O, Afolayan AJ. (2013b). Stability study of smoked fish, horse mackerel (Trachurus traichurus) by different methods and storage at room temperature. African Journal of Biochemistry Research 7(6): 98-106.

Akande GR. (1996). Nutritional Values of Smoked Clarias Gariepinus from Major Markets in Southwest, Nigeria. Global Journal of Science Frontier Research (D) 15(6): 33-34.

AOAC. (2000). Official Methods of Analysis, 17th ed. AOAC International, Gaithersburg, Maryland, USA.

Ayeloja AA. (2019). Sensory quality of smoked Clarias gariepinus (Burchell, 1822) as affected by spices packaging methods. International Journal of Food Properties 22(1): 704-13

Ayeloja AA, George FOA, Jimoh WA, Shittu MO, Abdulsalami SA. (2018). Microbial Load on Smoked Fish commonly traded in Ibadan, Oyo State, Nigeria Journal of Applied Science and Environmental Management 22(4): 493-497.

Ayeloja AA, George FOA, Obasa SO, Sanni L O, Ajayi AA. (2011a). Effects of length of delay after slaughter (LODAS) on raw catfish Clarias gariepinus. Journal of American Science 7(6): 508-512.

Ayeloja AA, George FOA, Obasa SO, Sanni LO. (2011b). Effect of post-slaughter time intervals on the quality of the African catfish, Clarias gariepinus (Burchell, 1822). American Journal of Food Technology 6(9): 790-797.

Ayeloja A A, George FOA, Akinyemi AA and Atanda OO. (2015). Proximate and mineral composition of spiced smoked catfish Clarias gariepinus (Burchell, 1822). Journal of Agricultural Science and Environ- 
ment 15(2): 68-74.

Daramola JA, Fasakin EA, Adeparusi EO. (2007). Changes in physicochemical and sensory characteristics of smoke-dried fish species stored at ambient temperature. African Journal of Food, Agriculture, Nutrition and Development 7(6): 1-16.

Ekelemu JK. (2010). Differential growth patterns of Clarias gariepinus, Heterobranchus bidorsalis and Hybrid Heteroclarias fed commercially prepared diets. Agriculture and Biology Journal of North America 1(4): 658-661.

ElShehawy SM, El-Fatah GAA, Mutwally HM. (2016). Amino Acids Pattern and Fatty Acids Composition of the Most Important Fish Species of Saudi Arabia. Research \& Reviews: Journal of Food and Dairy Technology 4 (3): 27-36.

Heliene LR, Porto AC, Leal C, Victor EMF, Gandhi R. (2016). Evaluation of the Chemical Composition of Fish Species Captured in the lower Stretch of Itapecuru River, Maranhao, Brazil. International Journal of Advances in Agricultural \& Environmental Engineering 3(1): 181-186.

Huss HH. (2004). Assurance of Sea food Quality. FAO of Fisheries Technical Paper 334, Food and Agriculture Organization.

Jinadasa BK. (2014). Determination of quality of marine fishes based on total volatile nitrogen Test (TVN). Nature and Science 12(5): 106-107.

Khanipour AA, Mirzakhani N. (2013). Effect of different packaging methods on shelf life of hot smoked rainbow trout (Oncorhynchus mykiss) during storage at $0-2^{\circ} \mathrm{C}$. Iranian Journal of Fisheries Sciences $12(3)$ : 620-628.

Kirk RS, Sawyer R. (1991). Nitrogen Determination. Pearson's Composition and Analysis of Foods. Longman Scientific Publisher: London, p. 29-36.

Marwa MM. (2015). Effects of freezing storage on the biochemical composition in muscles of Saurida undosquamis (Richardson, 1848) comparing with imported frozen. International Journal of Fisheries and Aquatic Studies 3(2): 295-299.

Mosarrat NN, Gulshan AL, Subhash CC, Farzana BF, Mohajira B. (2016). Shelf-life quality of smoke-dried freshwater SIS fish; Chapila (Gudusia chapra, Ham-
ilton-Buchanan; 1822) Kaika (Xenentodon cancila, Hamilton-Buchanan; 1822) and Baim (Mastacembelus pancalus, Hamilton-Buchanan; 1822) stored at laboratory condition (26-31oC). Journal of Agriculture and Veterinary Science 9(3): 23-32.

Obe BW. (2014). Growth performance and nutrient utilization of catfish hybrid (Heterobranchus bidorsalis $\mathrm{X}$ Clarias gariepinus) fed fermented sorghum (Sorghum bicolor) waste meal diets. International Journal of Applied Science and Technology 4(3): 130-136.

Owodeinde FG, Ndimele PE, Fakoya KA, Adewolu MA, Anetekhai MA. (2018). Growth performances of clarias gariepinus, Heterobranchus bidorsalis and their hybrid (Heteroclarias) in earthen ponds in Badagry, Southwest, Nigeria Department of Fisheries, Faculty of Science, Lagos State University. Nigerian Journal of Fisheries and Aquaculture 5(2): 122-131.

Pawar SM, Sonawane SR. (2013). Fish muscle protein highest source of energy. International Journal of Biodiversity and Conservation 5(7): 433-435.

Pinto JF. (2007). Feeding interruption and quality of cultured gilthead sea bream. Food Chemistry Journal 100: 1504-1510.

Ravichandran S, Kumaravel K, Florence PE. (2011). Nutritive composition of some edible fin fishes. International Journal of Zoological Research 7: 241-251.

Serkan K, Sevim K, Bekir T. (2010). The Effect of storage temperature on the chemical and sensorial quality of hot smoked Atlantic Bonito (Sardasarda, Bloch, 1838) packed in aluminum foil. Turkish Journal of Fisheries and Aquatic Science 10: 439-443.

Shiming P, Chao C, Zhaohong S, Lu W. (2013). Amino acid and fatty acid composition of the muscle tissue of Yellowfin Tuna (Thunnus Albacares) and Bigeye Tuna (Thunnus Obesus). Journal of Food and Nutrition Research 1(4): 42-45.

Zhao F, Zhuang P, Song C, Shi ZH, Zhang LZ. (2010). Amino acid and fatty acid compositions and nutritional quality of muscle in the pomfret, Pampus punctatissimus. Journal of Food Chemistry 118(2): 224-227.

Zulema CP. (2014). Chemical composition of fish and fishery products. In: Handbook of Food Chemistry, Springer-Verlag, Berlin Heidelberg. p. 1- 28. 